\title{
Decision Support System for Determining Land Priority for Housing Development Using Fuzzy Analytical Process (Fuzzy-AHP) Method
}

\author{
Allwin M Simarmata \\ Universitas Prima Indonesia \\ Medan, Indonesia \\ allwinsimarmata@unprimdn.ac.id
}

\author{
Yennimar \\ Universitas Prima Indonesia \\ Medan, Indonesia \\ Yennimar@unprimdn.ac.id
}

\begin{abstract}
The National Housing Development Public Corporation (Perumnas) was established as a government solution in providing adequate housing for the middle to lower classes, to realize this, Perumnas set a target of building 100,000 houses / year. The aspect of development is to ensure that all communities occupy decent homes in a healthy environment, an increase in the number of residents in the city, especially the city of Medan, causes settlement problems because the area of land is a fixed factor, while the population is always growing, thus requiring a system that can help decision in determining the priority of land for housing development. In this study an analysis of patterns related to applicable criteria or rules is implemented by applying the Fuzzy Analytical Hierarchy Process (FuzzyAHP) method, to produce accurate and effective information for making priority decisions on the location of the best residential development land. The analysis framework uses a data collection approach sourced from Public Relations, then an analysis is carried out to determine the criteria, rules and standards used, then a system is built by implementing the Fuzzy-AHP method to produce optimal alternatives that can be used as information. Alternative results will be evaluated by quantitative and qualitative analysis compared to the existing system. The developed system is expected to be used as a tool in decision making in the Regional Sumatra Regional Public Corporation I company that is optimal according to the criteria, rules or standards used. Data collection using the method of literature study, observation, interviews, and sampling. This research is expected to be one of the references in the application of decision support systems in a real scope and contribute to building a constructive community culture based on logical and scientific values.
\end{abstract}

Keywords - Fuzzy-AHP, Multy Attribute Decision Making (MADM), priority location for development land, Perumnas

\section{INTRODUCTION}

National Housing Development Public Corporation (Perumnas) is a State-Owned Enterprise (BUMN) in the form of a Public Corporation (Perum) in which the entire shares are owned by the Government. Perumnas was established as a government solution in providing a research background of no more than 500 words containing the background and issues to be studied, specific objectives, and urgency of the study. In this section it is necessary to explain the description of special specifications related to the scheme. decent housing for the lower middle class. In accordance with the long-term plan, Perumnas is heading towards National Housing \& Urban Corporation by becoming the main actor in housing and settlement providers in Indonesia. To realize this, Perumnas has set a target of building 100,000 houses / year, but in its implementation it often faces obstacles, especially the problem of determining the location of residential development land. The housing aspect is an important aspect in urban activities and activities. This is due to housing being the largest land user of urban built land, around 
$40 \%$ of the land built in the Spatial Plan (RTR), while other uses are for open space and industry.

From the above conditions, it appears that the housing aspect has the potential to cause problems in urban land use. The increase in urban and sub-urban population and the development of urban activities require a large supply of housing, but currently the supply of cheap housing is still insufficient. Conditions like these that raise the problem of settlements, the imbalance between demand and the provision of cheap housing. In addition, environmental degradation, unequal distribution of housing, and inadequate housing facilities will lead to problems with slums. In addition, due to the lack of land supply and low-cost housing in urban areas, the emergence of illegal settlements results in a system that can help decision makers make the best decisions.

\section{LITERATURE REVIEW}

Multy Attribute Decision Making (MADM) is a way to find optimal alternatives from a number of alternatives with certain criteria. The MADM method is widely proposed by researchers in decision-making issues such as recommendations for the sale of mobile accessories, (Widyasuti, 2017), homes (Indrarti, 2018), determination of housing locations (Borman, 2018), determination of examiner lecturers and supervisors (Septiana, 2017), promotion position (Chan, 2018), selection of manuscripts worth publishing (Ekastini, 2017), determination of station location (Nurdiansyah, 2018) and others.

Analitycal Hierarchy Process (AHP) is one of the right and effective methods in handling complicated decision making so that it can be used to help decision makers in determining priorities and the best decisions (Saaty, 2008), but criteria that have more subjective nature, uncertainty factors numbers are represented in order of scale, making it difficult to determine the exact scale value of importance. Fuzzy Analytical Hierarchy Process (Fuzzy-AHP) is a combination of the AHP method with the fuzzy concept approach. The application of fuzzy concepts in AHP allows to obtain more accurate results from several criteria of the decision making process (Beşikçi, et al., 2016), and is better at describing vague decisions than AHP (Joni, 2014).

In this study an analysis of land priority determination patterns will be carried out using the Fuzzy-AHP method approach to produce appropriate and effective alternatives, then an evaluation with a quantitative and qualitative analysis is compared with the existing system. The developed system is expected to be used as a tool for decision makers in the North
Sumatra Perumnas Regional I BUMD company in determining the decision to determine optimal housing development land priorities according to the criteria, rules or standards used.

\section{Proposed Method}

Broadly speaking, the overall stages of the study are as follows, in Figure 1.

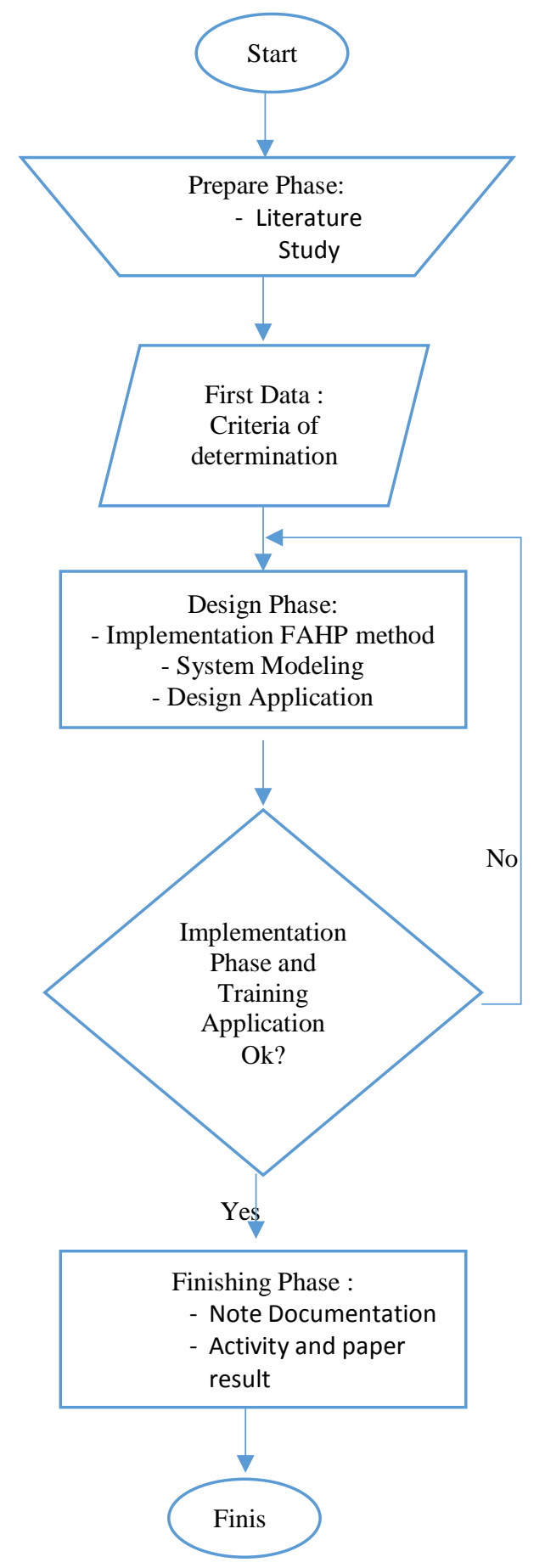


Figure 1. Research Phase

The following explanation of the stages of research conducted.

1. Preparation stage. Research activities are focused on the study of literature, enrichment of content and research context, and field surveys. From this stage, the preliminary data are obtained, namely the criteria for determining the provision of credit.

2. The design stage. At this stage the system design is carried out including:

a. The application of the Fuzzy Analytical Hierarchy Process (F-AHP) method includes:

- Determine the types of alternative criteria

- Arrange criteria, sub-criteria and value interests in a paired matrix.

- Add up each column in the paired matrix

- Determine the value of the criteria column element with the formula for each cell in the paired comparison table divided by the number of columns in step 3

- Determine the priority of the criteria on each of them by the formula of the number of rows divided by many criteria.

- Calculates the maximum, CI and CR. $\Lambda$

- Conversion of pairwise comparison matrices between criteria into fuzzy number scale

- Determine the value of fuzzy synthesis

- Determine the vector value $(\mathrm{V})$ and defuzzification ordinate value ( $\mathrm{d}$ ')

- Normalized fuzzy weight values (W)

b. System Modeling

c. Application design

a. Display design

b. Database Design

d. Implementation and Testing Phase. This stage is intended as a step testing the performance of application programs.

e. Stage of completion. The stage in which the activity notes and research results are documented

\section{Data}

In this study the data used for the proposed system testing needs were sourced from the North Sumatra
Regional Housing I, Jl. Matahari Raya No. 313

Helvetia Medan City, following the data used.

Table 1 Data Type Houses

\begin{tabular}{|c|c|c|c|c|c|c|c|c|c|c|c|}
\hline & \multirow[b]{3}{*}{ Type Rumah } & \multirow[b]{3}{*}{ Lokasi } & \multirow{3}{*}{$\begin{array}{l}\text { NAMA } \\
\text { JALAN }\end{array}$} & \multirow[b]{3}{*}{ DMJ } & \multirow[b]{3}{*}{ NDR } & se & uses & & & & \\
\hline \multirow[b]{2}{*}{ No } & & & & & & \multicolumn{6}{|c|}{ LUAS KAVLING } \\
\hline & & & & & & PJG $\left(M^{\prime}\right)$ & LBR $(M)$ & LUAS (M2) & STD (M2) & KLT & (M2) \\
\hline 1 & \begin{tabular}{|l|} 
TYPE \\
RST.30/75 \\
DOWNGRADE
\end{tabular} & $\begin{array}{l}\text { MARTUBCNG-III } \\
\text { BLOK-01, 02, 07 } \\
\& 08\end{array}$ & $\begin{array}{l}\text { SALMON } \\
\text { RAYA }\end{array}$ & 10 & $\mathrm{E}_{2}$ & 15 & & 90 & 75 & & 15 \\
\hline 2 & \begin{tabular}{|l|} 
TYPE \\
RS 45/120
\end{tabular} & $\begin{array}{l}\text { MARTUBUNG-III } \\
\text { BLOK-01 } 02\end{array}$ & $\begin{array}{l}\text { SALMON } \\
\text { RAYA }\end{array}$ & 10 & B33 & 15 & & 120 & 120 & & \\
\hline 3 & \begin{tabular}{|l} 
TYPE \\
RST.36/84
\end{tabular} & $\begin{array}{l}\text { MARTUBUNG-III } \\
\text { BLOK-01 \& } 02\end{array}$ & $\begin{array}{l}\text { MAGNOLII } \\
\text { ARAYA }\end{array}$ & 10 & B1 & 13 & & 91 & 91 & & . \\
\hline 4 & TYPE RS $30 / 75$ & $\begin{array}{l}\text { MARTUBUNG-III } \\
\text { BLOK-07 08 }\end{array}$ & TULIP -I & 6 & E1 & 12.5 & & 75 & 75 & & \\
\hline 5 & TYPE RKO & \begin{tabular}{|l} 
MARTUBUNG-III \\
BLOK-07 TULIP
\end{tabular} & TULIP - I & 6 & E1 & 12.5 & & 75 & 75 & & . \\
\hline 6 & TYPE RS. $31 / 75$ & \begin{tabular}{|l|} 
MARTUBUVIG-III \\
BLOK-001
\end{tabular} & \begin{tabular}{|l|} 
SALMON \\
VIII
\end{tabular} & 6 & 493 & 12.5 & & 75 & 75 & & . \\
\hline 7 & $\begin{array}{l}\text { TYPE } \\
\text { RST. } 36 / 91\end{array}$ & $\begin{array}{l}\text { MARTUBUNG-III } \\
\text { BLOK-07 } 08\end{array}$ & $\begin{array}{l}\text { TULIP } \\
\text { RAYA }\end{array}$ & 10 & M1 & 13 & & 91 & 91 & & \\
\hline
\end{tabular}

Table 2. Details of Data

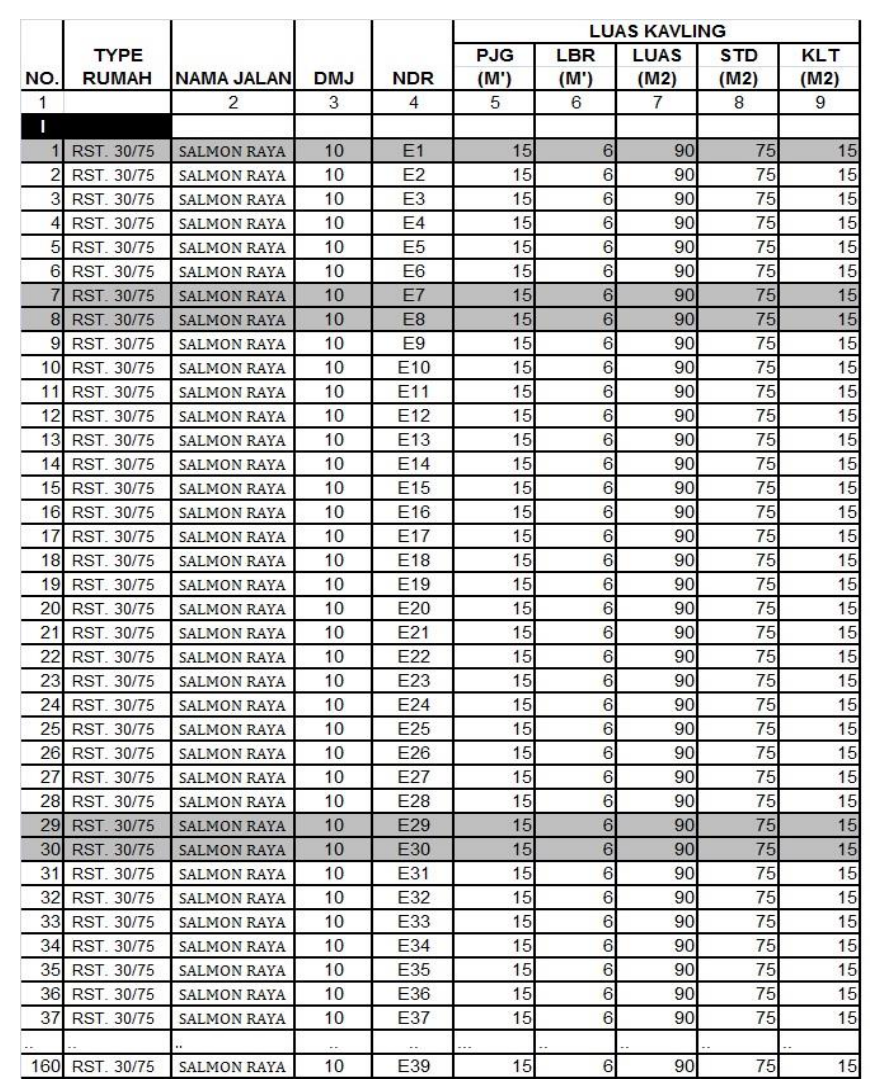

IV. Result AND Discussion

The application of the Fuzzy Analytical Hierarchy Process (F-AHP) method is carried out in several stages, namely:

a. Criteria Variable

Define assessment criteria and alternatives arranged based on the AHP hierarchical structure. This stage is 
also called the data input design stage. The results of defining the criteria and alternatives are stored in a database to make it easier in the next step, the criteria variable table is seen in table 3 .

Table 3. Criteria Variables

\begin{tabular}{|c|c|c|c|c|}
\hline \multirow[t]{2}{*}{ No } & \multirow{2}{*}{\multicolumn{2}{|c|}{ Criteria }} & \multicolumn{2}{|c|}{ Valuation Aspect } \\
\hline & & & Information & Bobot \\
\hline \multirow[t]{4}{*}{1} & \multirow{4}{*}{$\begin{array}{l}\text { House } \\
\text { Type } \\
\text { (core } \\
\text { factor) }\end{array}$} & \multirow[t]{4}{*}{$\mathrm{C} 1$} & RS.45/120 & 4 \\
\hline & & & RST.36/84 & 3 \\
\hline & & & RS.30/75 & 2 \\
\hline & & & RST.36/91 & 1 \\
\hline \multirow[t]{4}{*}{2} & \multirow{4}{*}{$\begin{array}{l}\text { (core } \\
\text { factor) }\end{array}$} & \multirow[t]{4}{*}{$\mathrm{C} 2$} & Very Near & 4 \\
\hline & & & Near & 3 \\
\hline & & & Far & 2 \\
\hline & & & So Far & 1 \\
\hline \multirow[t]{4}{*}{3} & \multirow{4}{*}{$\begin{array}{l}\text { (core } \\
\text { factor) }\end{array}$} & \multirow[t]{4}{*}{ C3 } & So Wide & 4 \\
\hline & & & Wide & 3 \\
\hline & & & Less Wide & 2 \\
\hline & & & Not Wide & 1 \\
\hline \multirow[t]{4}{*}{4} & \multirow{4}{*}{$\begin{array}{l}\text { NDR } \\
\text { (secondary) }\end{array}$} & \multirow[t]{4}{*}{$\mathrm{C} 4$} & $>10$ & 4 \\
\hline & & & 10 & 3 \\
\hline & & & $<10$ & 2 \\
\hline & & & 0 & 1 \\
\hline \multirow[t]{4}{*}{5} & \multirow{4}{*}{$\begin{array}{l}\text { Kavlin } \\
\text { (secondary) }\end{array}$} & \multirow[t]{4}{*}{$\mathrm{C5}$} & $>120$ & 4 \\
\hline & & & $90-100$ & 3 \\
\hline & & & $60-90$ & 2 \\
\hline & & & $<50$ & 1 \\
\hline
\end{tabular}

Table 4. Weight of Gap Value

\begin{tabular}{|c|c|c|}
\hline $\begin{array}{c}\text { Diffe } \\
\text { renc } \\
\text { e }\end{array}$ & $\begin{array}{c}\text { Score } \\
\text { Bobot }\end{array}$ & Information \\
\hline 0 & 5 & $\begin{array}{c}\text { There is no difference } \\
\text { (Competency according to what } \\
\text { is needed }\end{array}$ \\
\hline 1 & 4,5 & $\begin{array}{c}\text { Individual competence is 1 level } \\
\text { / level }\end{array}$ \\
\hline-1 & 4 & $\begin{array}{c}\text { Individual competencies lack 1 } \\
\text { level / level }\end{array}$ \\
\hline 2 & 3,5 & $\begin{array}{c}\text { Individual competence has an } \\
\text { excess of 2 levels / levels }\end{array}$ \\
\hline-2 & 3 & $\begin{array}{c}\text { Individual competencies lack 2 } \\
\text { levels / levels }\end{array}$ \\
\hline 3 & 2 & $\begin{array}{c}\text { Individual competencies are over } \\
\text { 3 levels / level }\end{array}$ \\
\hline-3 & 2,5 & $\begin{array}{c}\text { Individual competencies lack 3 } \\
\text { levels / levels }\end{array}$ \\
\hline 4 & 1,5 & $\begin{array}{c}\text { Individual competence is over 4 } \\
\text { levels / level }\end{array}$ \\
\hline-4 & 1 & $\begin{array}{c}\text { Individual competencies lack 4 } \\
\text { levels / levels }\end{array}$ \\
\hline
\end{tabular}

a. Alternative variable

In this study alternatives are subjects that will be assessed for the suitability of the house type and condition. However, in this study only using sample data for testing systems and methods designed. In this study only used 3 samples for testing and weighting values for each alternative randomly.

\begin{tabular}{c} 
Tabel 5. Alternatif \\
\hline Variabel \\
\hline A1 \\
A2 \\
A3
\end{tabular}

Tabel 6. Bobot alternatif

\begin{tabular}{|r|r|r|r|r|r|}
\hline & C1 & C2 & C3 & C4 & C5 \\
\hline A1 & 2 & 4 & 3 & 3 & 4 \\
\hline A2 & 2 & 1 & 2 & 4 & 2 \\
\hline A3 & 3 & 2 & 4 & 4 & 3 \\
\hline
\end{tabular}

\section{a. Example of Settlement}

1. Calculation of Matrix Value

AHP calculation is useful for finding consistency of comparison matrix values. Input the AHP comparison matrix values as follows:

Table 7 Matrix Calculations

\begin{tabular}{|c|c|c|c|}
\hline & $\mathrm{C} 1$ & $\mathrm{C} 2$ & $\mathrm{C} 3$ \\
\hline $\mathrm{C} 1$ & $\mathbf{1}$ & $\mathbf{3}$ & $\mathbf{5}$ \\
\hline $\mathrm{C} 2$ & $1 / 3$ & $\mathbf{1}$ & $\mathbf{3}$ \\
\hline $\mathrm{C} 3$ & $1 / 5$ & $1 / 3$ & $\mathbf{1}$ \\
\hline Jumlah & 1.533 & 4.333 & 9 \\
\hline
\end{tabular}

The input value of the comparison matrix above is then processed to find the priority vector weights, lamda, $\mathrm{CI}$, and CR. Before calculating the priority weight value, each cell in the column matrix is divided by the number of columns in each cell.

$$
\begin{aligned}
& \mathrm{C} 1=\frac{1}{1533}=0.6522 \\
& \mathrm{C} 2=\frac{1 / 3}{1533}=0.2074 \\
& \mathrm{C} 3=\frac{1 / 5}{1533}=0.1302
\end{aligned}
$$

And so on until finished 
Calculate the priority weight value, which is the result of cell division that has been obtained in each row of the matrix is added up, then divided by the number of cells in the row (many criteria $=3$ )

Table 8 priority weights

\begin{tabular}{|c|c|c|c|c|}
\hline & $\mathrm{Cl}$ & $\mathrm{C} 2$ & $\mathrm{C} 3$ & $\begin{array}{l}\text { Bobot prioritas } \\
\text { (Eigenvevtor) }\end{array}$ \\
\hline \multirow[b]{2}{*}{$\mathrm{Cl}$} & 0.652 & 0.692 & 0.556 & 0.633 \\
\hline & \multicolumn{3}{|c|}{$=\frac{0.622+0.692+0.556}{3}=0.633$} & \\
\hline \multirow[b]{2}{*}{$\mathrm{C} 2$} & 0.217 & 0.231 & 0.333 & 0.260 \\
\hline & \multicolumn{3}{|c|}{$=\frac{0.217+0.231+0.333}{3}=0.260$} & \\
\hline \multirow[b]{2}{*}{$\mathrm{C} 3$} & 0.130 & 0.077 & 0.111 & 0.106 \\
\hline & \multicolumn{3}{|c|}{$=\frac{0.130+0.077+0.111}{3}=0.106$} & \\
\hline \multicolumn{4}{|c|}{ Jumlah } & 1 \\
\hline
\end{tabular}

Calculating the value of lamda is multiplying the eigenvector and the number of cell columns in the table above and counting the $\mathrm{CI}$ and $\mathrm{CR}$ values.

$$
\begin{aligned}
\lambda \text { maks } & =(0.633 \times 1.533)+(0.260 \times 4.33)+(0.106 \times 9) \\
& =\mathbf{3 . 0 5 5 4} \\
\mathrm{CI} \quad & =\mathbf{0 . 0 2 7 7}(\boldsymbol{n}=\mathbf{3}, \boldsymbol{R} I=0.58), \text { dipeoleh nilai } \mathrm{CR} \\
\mathrm{CR} \quad & =\mathbf{0 . 0 4 7 7} \text { (Konsisten) }
\end{aligned}
$$

Convert AHP comparison values to fuzzy set values (F-AHP) using the previous table. The results of the conversion value of the comparison matrix are as follows.

Table 9 Comparison of Criteria

\begin{tabular}{|c|c|c|c|c|c|c|c|c|c|}
\hline & \multicolumn{3}{|c|}{$\mathrm{Cl}$} & \multicolumn{3}{c|}{$\mathrm{C} 2$} & \multicolumn{3}{c|}{ C3 } \\
\hline $\mathrm{Cl}$ & 1 & 1 & 1 & 1 & 1.5 & 2 & 2 & 2.5 & 3 \\
\hline $\mathrm{C} 2$ & 0.5 & 0.6667 & 1 & 1 & 1 & 1 & 1 & 1.5 & 2 \\
\hline $\mathrm{C} 3$ & 0.3333 & 0.4 & 0.5 & 0.5 & 0.667 & 1 & 1 & 1 & 1 \\
\hline
\end{tabular}

1. Determine the value of fuzzy synthesis ( $\mathrm{Si}$ )

To determine the value of fuzzy synthesis (si) priority with the formula equation. The results of processing

\begin{tabular}{|c|c|c|c|c|c|c|}
\hline \multirow[b]{2}{*}{ Cl } & \multicolumn{3}{|c|}{$\sum_{j=1}^{m} M_{g i}^{j}$} & \multicolumn{3}{|c|}{$S i$} \\
\hline & 4 & 5.00 & 6 & 0.320 & 0.489 & 0.720 \\
\hline $\mathrm{C} 2$ & 2.50 & 3.167 & 4 & 0.200 & 0.309 & 0.480 \\
\hline C3 & 1.83 & 2.067 & 3 & 0.147 & 0.202 & 0.300 \\
\hline$\sum_{i=1}^{n} \sum_{j=1}^{m} M_{g i}^{j}$ & 8.333 & 10.234 & 13 & & & \\
\hline
\end{tabular}
the table above can be obtained as the value of the synthesis table below.

Table 10 Fuzzy synthesis values (Si)
If the $\mathrm{Si}$ value is obtained, it can be defined as a vector (V) value:
a. $\quad \mathrm{Vsc} 1 \geq(\mathrm{Vsc} 2, \mathrm{Vsc} 3)$
$\mathrm{Vsc} 1 \geq \mathrm{Vsc} 2=1$
$\mathrm{Vsc} 1 \geq \mathrm{Vsc} 3=1$
b. $\quad \mathrm{Vsc} 2 \geq(\mathrm{Vsc} 1, \mathrm{Vsc} 3)$
$\mathrm{Vsc} 2 \geq \mathrm{Vsc} 1=0.472$
$\mathrm{Vsc} 2 \geq \mathrm{Vsc} 3=1$
c. $\quad \mathrm{Vsc} 3 \geq(\mathrm{Vsc} 1, \mathrm{Vsc} 2, \mathrm{Vsc} 4)$
$\mathrm{Vsc} 3 \geq \mathrm{Vsc} 1=0$
$\mathrm{Vsc} 3 \geq \mathrm{Vsc} 2=0.482$

\section{Display Application}

The next stage is testing the data used in applications developed using the Fuzzy Analytical Hierarchy Process (Fuzzy-AHP) method. Next is the display application that has been developed. The application display consists of several menus, namely:

a) Login page

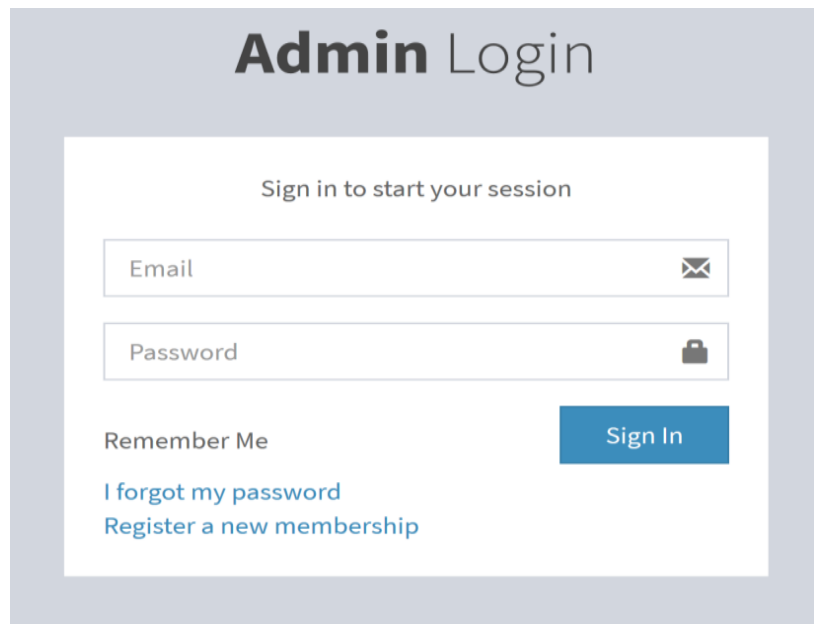

Figure 2 Login Menu

b) Criteria page 


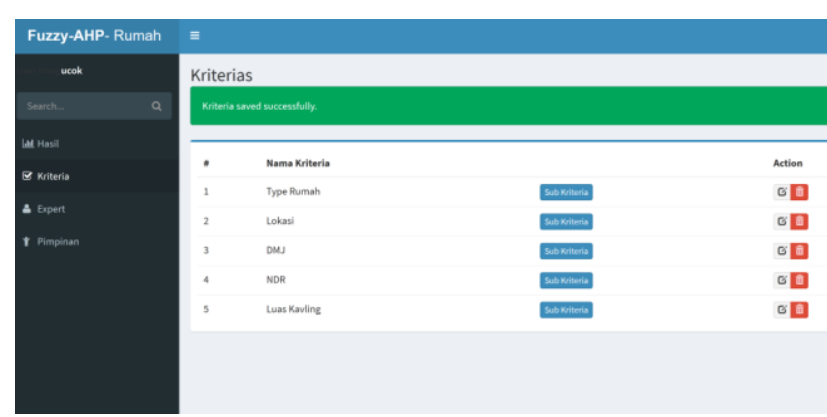

Figure 3 Criteria Page

b) Sub Criteria page

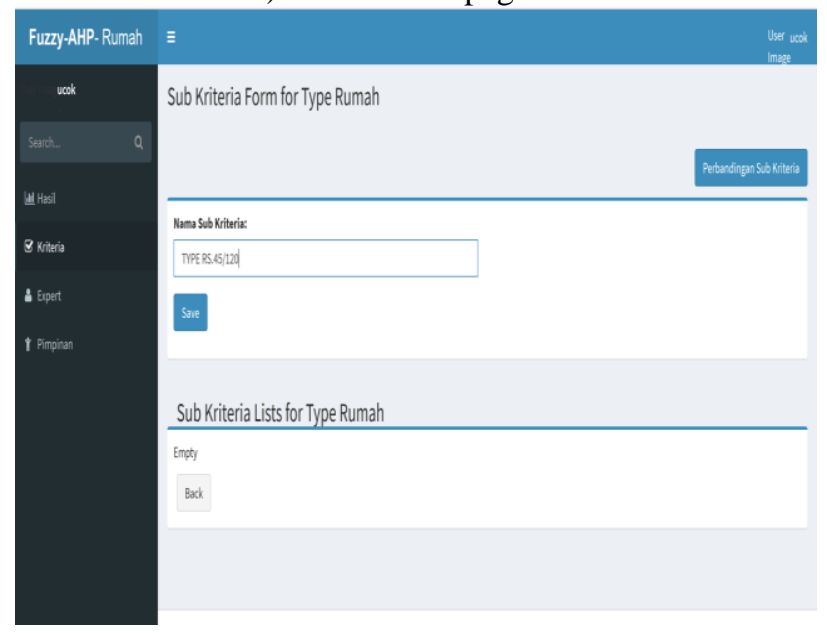

Figure 4 Entry Criteria page

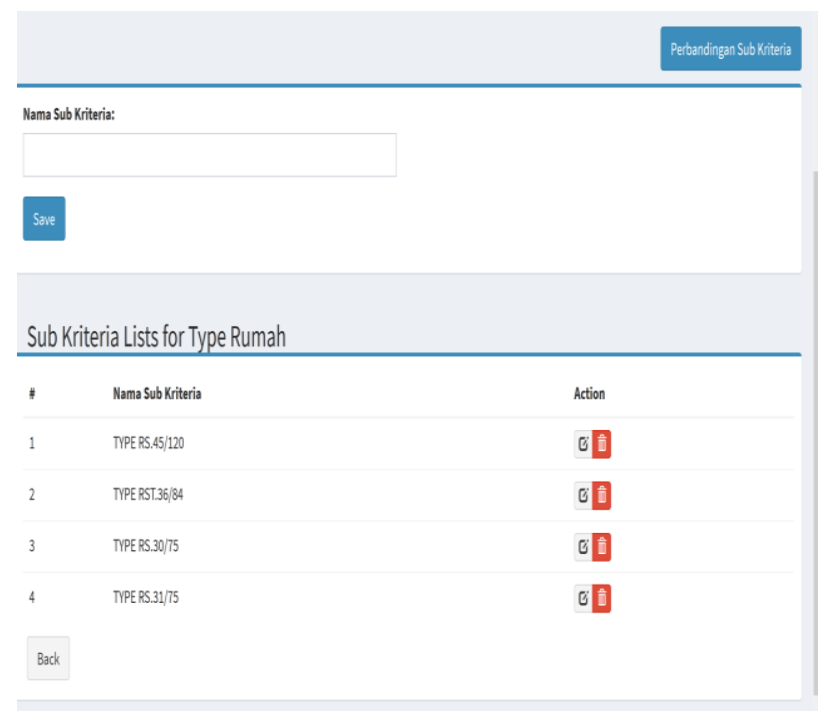

Figure 5. List of Sub Criteria b) Supplier Page

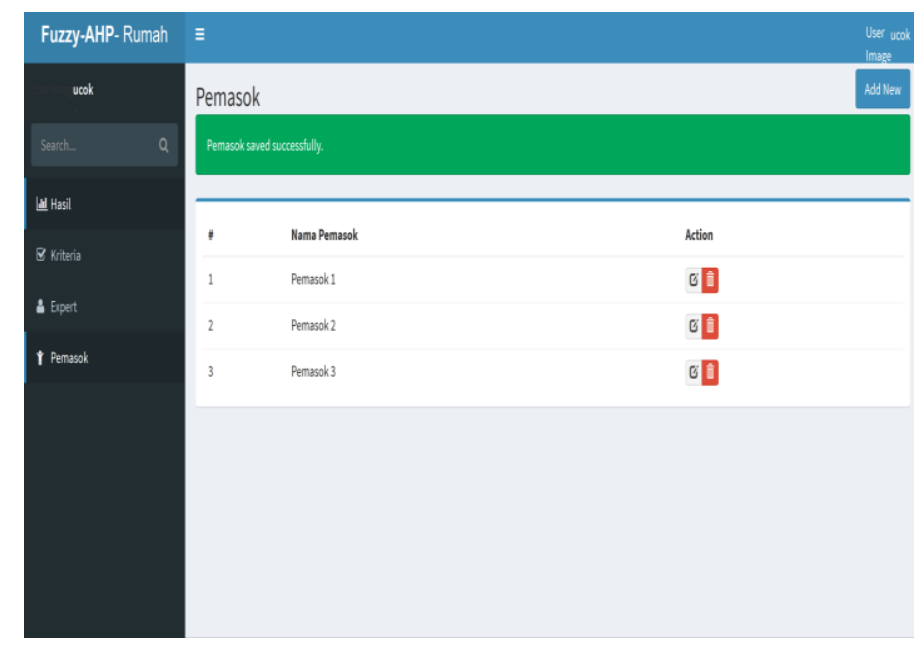

Figure 6 Supplier Page

c) Expert page

\begin{tabular}{|c|c|c|c|c|c|}
\hline \multirow{11}{*}{ 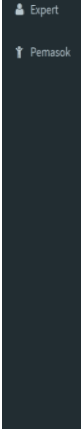 } & . & Kriteria1 & Milai & Kriteriar2 & Action \\
\hline & 1 & Typerumah & 4 & Lohasi & 厄 \\
\hline & 2 & Type Rumahh & 3 & ons & E \\
\hline & 3 & Typerumah & 2 & NOR & 厄 \\
\hline & 4 & Typerumanh & 4 & Luas Kaving & ๔ \\
\hline & 5 & Lohasi & 2 & ons & E \\
\hline & 6 & Lohasi & 3 & NOR & 厄 \\
\hline & 7 & Latassi & 3 & Lus Karing & E \\
\hline & 8 & DWJ & 2 & NOR & E \\
\hline & 9 & DWJ & 1 & Luas Kayling & 厄) \\
\hline & 10 & NOR & 3 & Luas Kaviling & ఠ \\
\hline
\end{tabular}

Figure 7 Comparison Expretary Page Criteria Matriks

\begin{tabular}{llllll}
\hline & Type Rumah & Lokasi & DMJ & NOR & Luas Kaving \\
Type Rumah & 1 & 4 & 3 & 2 & 4 \\
Lokasi & 0.25 & 1 & 2 & 3 & 3 \\
DMJ & 0.333 & 0.5 & 1 & 2 & 1 \\
NOR & 0.5 & 0.333 & 0.5 & 1 & 3 \\
Lusk Kaving & 0.25 & 0.333 & 1 & 0.333 & 1 \\
\hline & & & & & \\
\hline
\end{tabular}

Figure 8 Comparison Matrix 


\section{d) Results Page}

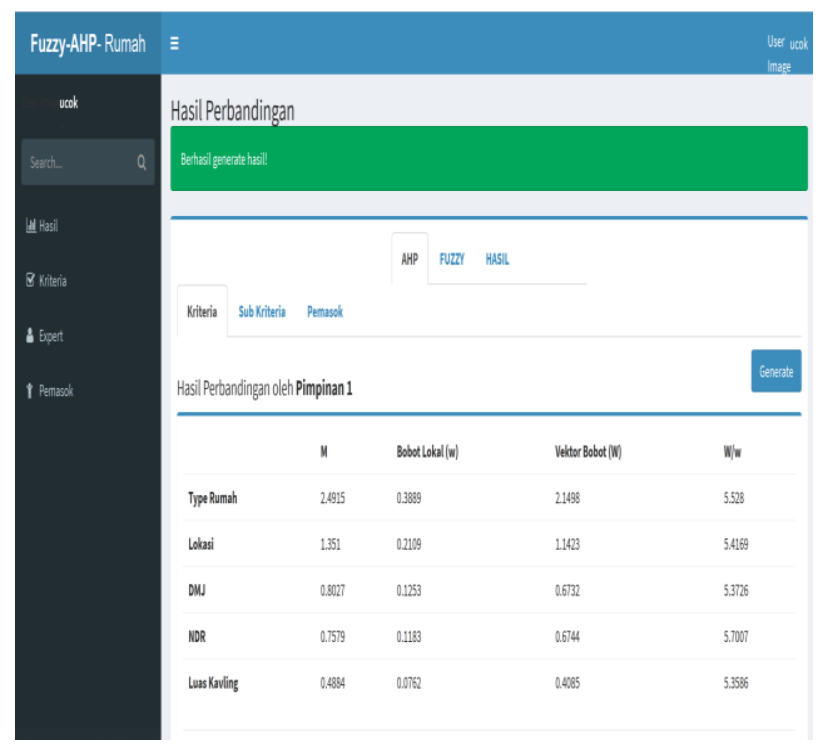

Figure 9 Results Page

\section{CONClusion AND Suggestion}

Alternative results were evaluated by quantitative and qualitative analysis compared to the existing system. The developed system can be used as a tool in decision making in the Regional General Corporation North Sumatra Regional BUMD company that is optimal according to the criteria, rules or standards used. This research is expected to be one of the references in the application of decision support systems in a real scope and contribute to building a constructive community culture based on logical and scientific values.

\section{ACKNOWLEDGMENT}

Thank you to:

1. Kemenristekdikti which has provided assistance in the form of financial support.

2. Universitas Prima Indonesia, which has provided motivational support and facilities.

3. The National Housing Development General Corporation (Perumnas) Medan North Sumatra Branch is willing as a partner, providing a dataset.

\section{REFERENCES}

Joni, I., D., Ariana, A., A., 2014, Supporting System for the Selection of Permanent Lecturer
Selection Supporters with the AHP Fuzzy Method, NERO Scientific Journal, Vol. 1, No. 2, Hal. 23-32.

Faisol, A., Muslim, M. A., \& Suyono, H., 2014, Comparison of Fuzzy AHP with AHP in the Property Investment Decision Support System, EECCIS Journal Vol. 8, No. 2, pp. 123-128.

Perdanawanti, L., 2016, Bnagun Design Information Systems Decision Support Systems Determination of Alert Villages in Kalibagor Health Center, Banyumas Regency, Telematics Journal, Vol. 9, pp.27-41.

Beşikçi, E. B., Kececi, T., Arslan, O. \& Turan, O., 2016. An Application of Fuzzy-AHP to Ship Operational Energy Eficiency Measures. Ocean Engineering, 121, 392-402.

Indrarti, W., \& Marlinda, L., 2017, Home Decision Support System Using the Promethee, Synchronous, Journal \& Informatics Engineering Research Method, Volume 2 Number 2, e-ISSN: 2541-2019, pp. 172-175.

Widyasuti, M., Wanto, A., Hartama, D., Purwanto, E., 2017, Recommendations for Mobile Accessories Sales Using the Analitycal Hierarchy Process (AHP) Method, KOMIK (National Conference on Information and Computer Technology), Volume I, Number 1 , ISSN 2597-4645 (online media), pp. 27-32.

Ekastini, Kusrini, Lutfi, E. T., 2017, Application of the Fuzzy Analytical Hierarchy Process Method for SPK Selection of Publishable Texts, Citec Journal, Vol. 4, No. 2, ISSN: 2460-4259, pp. 177-127.

Septiana, I., Irfan, M., Atmadja, AR, Subaeki, B., 2016, Decision Support System for Deciding Lecturers and Supervisors of Final Projects Using Fuzzy Multiple Attribute Decision Making with Simple Additive Weighting (Case Study: Department of Informatics UIN SGD Bandung), JOIN, Volume I No. 1, ISSN 25279165, pp. 43-50.

Chan, AS, Hasibuan, RI, Saputra, D., 2018, Analytical Hierarchy Process and Fuzzy Topsis in the Position Promotion Decision Support System at PT.Bandar Madani 165, Collection of Computer Science (KLIK) Volume 05, No.01, ISSN: 2406-7857, pp. 1-14.

Borman, R. I., Mayangsari., Muslihudin, M., 2018, Decision Support System for Determining Housing Locations in South Pringsewu Using 
Fuzzy Multiple Attribute Decision Making, JTKSI, Vol.01 No.01, pp. 4-9.

Bayu Nurdiansyah, B \& Yuliusman, 2018, Analysis of the Use of the Analytical Hierarchy Process Method for Determining the Location of the Construction of Gas Fuel Filling Stations in the Context of Reducing Greenhouse Gas Emissions (Co2) in Semarang City, Mathematics Education at Muhammadiyah University Purworejo, pp. 115-129.
Rachmat, 2014, Design of Application for Calculation and Distribution of Zakat Mal, Information and Scientific Technology, ISSN: 2339-210X, Volume IV, Number 3.

Setiawan et al. 2012, Implementation of Decision Support Systems in Furniture Suppliers Using the Promethee Model, Petra Christian Industrial Technology Faculty, Surabaya 